\title{
Herpes Simplex Keratitis and Dendritic Cells at the Crossroads
}

\section{Citation}

Hamrah, Pedram, Deborah Pavan-Langston, and Reza Dana. 2009. "Herpes Simplex Keratitis and Dendritic Cells at the Crossroads." International Ophthalmology Clinics 49 (1): 53-62. doi:10.1097/iio.0b013e3181924dd8.

\section{Published Version}

10.1097/iio.0b013e3181924dd8

\section{Permanent link}

http://nrs.harvard.edu/urn-3:HUL.InstRepos:34854261

\section{Terms of Use}

This article was downloaded from Harvard University's DASH repository, and is made available under the terms and conditions applicable to Other Posted Material, as set forth at http:// nrs.harvard.edu/urn-3:HUL.InstRepos:dash.current.terms-of-use\#LAA

\section{Share Your Story}

The Harvard community has made this article openly available.

Please share how this access benefits you. Submit a story.

Accessibility 


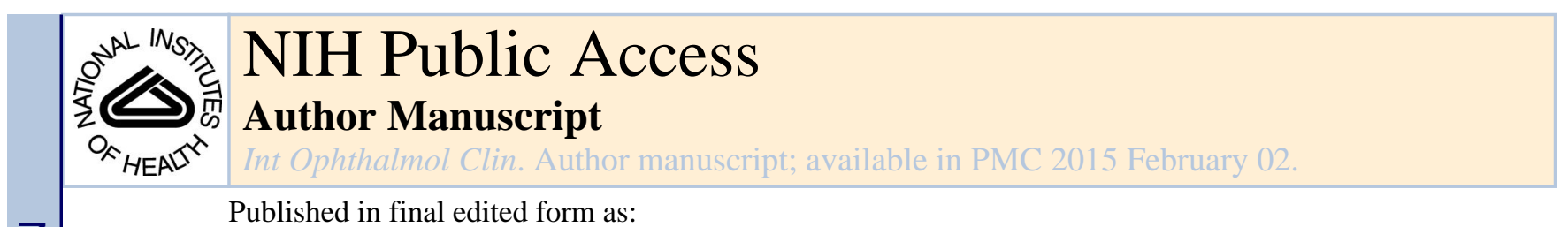

Published in final edited form as:

Int Ophthalmol Clin. 2009 ; 49(1): 53-62. doi:10.1097/IIO.0b013e3181924dd8.

\section{Herpes Simplex Keratitis and Dendritic Cells at the Crossroads: Lessons from the Past and a View into the Future \\ Pedram Hamrah, MD, Deborah Pavan-Langston, MD, FACS, and Reza Dana, MD, MSc, MPH}

\section{Introduction}

Herpes simplex keratitis (HSK) is the leading infectious cause of corneal blindness in the Western Hemisphere. The term "herpes" is derived from the Greek word herpein, which means "to creep," and stands for the characteristic creeping of the eruptions caused by the virus. HSK is a multifaceted disease, able to induce some of the most difficult management problems to Ophthalmologists through both immune and infectious mechanisms. In older children and adults, $78 \%$ to $98 \%$ of cases are due to herpes simplex virus (HSV)-1, ${ }^{1,2}$ whereas keratitis in neonates is more likely due to HSV-2. A study by Liesegang et $\mathrm{al}^{3}$ reported the annual incidence of new cases of ocular HSV at 8.4/100,000 and the annual incidence of all episodes at 20.7/100,000. The prevalence of ocular HSV was reported at $149 / 100,000$ population with $12 \%$ having bilateral disease.

Recent renewal of the classification of HSK recognizes disease entities as epithelial disease, immune or necrotizing stromal keratitis, neurotrophic keratopathy, and endotheliitis. ${ }^{4,5}$ Epithelial disease can further be subdivided into dendritic, geographic ulcers, and metaherpetic disease. Although HSV can replicate and destroy corneal epithelial cells, permanent vision loss and blindness occurs due to herpetic stromal keratitis. The stromal inflammatory response is thought to be due to replicating virus or the alteration of antigenicity of stromal cells, allowing for recurrent immune-mediated episodes of inflammation.

The cellular infiltrate of the stromal inflammatory response consists of macrophages, lymphocytes, polymorphonuclear cells, and plasma cells. Further analysis of T cells indicates that most of these cells express CD4's, which is typically expressed on T-helper cells. HSK is further characterized by Cowdry type A epithelial intranuclear inclusion bodies, and multinucleated giant cells that can be found in the proximity of Bowman's layer and Descemet's membrane. Long-standing disciform keratitis is further characterized by a granulomatous reaction to Descemet's membrane that includes epithelioid cells and giant cells. Moreover, viral particles can be found in the epithelium or stroma by electron microscopy, both in the nucleus or cytoplasm. However, the virus resides in sensory ganglia, particularly in the trigeminal ganglia, and transmission along axons seems to be a source for recurrent infection. 
The most striking feature of HSV is its capability to establish lifelong latency after primary infection. This feature allows HSV to persist unperceived in the host, allowing for periodical reactivation and infectious outbreaks. HSV has developed a multitude of strategies to evade the immune system during the reactivation phase. These strategies are comprised of viral escape that can be achieved through reduction of the viral gene expression during the latency phase; viral resistance through the induction of pro-apoptotic and anti-apoptotic effects on defender cells; and viral counter-attacks through the inhibition of dendritic cell (DC) maturation.

\section{Dendritic Cells}

Paul Langerhans discovered a population of DCs in the suprabasal regions of the skin epidermis by impregnating human skin with gold chloride as part of an open competition organized by the Berlin University in $1868 .{ }^{6}$ The branched skin cells resembling neuron, as described in his paper, are now referred to as Langerhans cells (LCs), a population of DCs. DCs are sentinel cells of haematopoietic origin that function as professional antigenpresenting cells (APCs). DCs are sparsely but widely distributed and are specialized to capture, process, and present antigens to T cells. The interaction of DCs with naive T cells can lead to immune response or T-cell tolerance, depending on the type of DCs. Since the initial description of DCs by Steinman and Cohn, ${ }^{7}$ it has become evident that there are many distinct DC subtypes, each with a particular location and specialized function in the immune system. ${ }^{8}$ To date, LCs of the corneal epithelium are the most widely known subtype of DCs to ophthalmologists.

The precursors of DCs are seeded through the blood into non-lymphoid tissues, where they develop to a stage referred to as "immature" DCs. Immature DCs are characterized by a high capacity for antigen capture and processing, but a low T-cell stimulatory capability. Immature DCs have a low to negligible amount of major histocompatibility complex (MHC) class II expression and lack the requisite accessory (costimulatory) signals for T-cell activation. Maturation of DCs that turns them into potent T-cell stimulators, is triggered by pathogens, by viral products, or by stimuli such as proinflammatory cytokines. ${ }^{9,10} \mathrm{DC}$ maturation leads to a marked increase in the surface expression of MHC class II and costimulatory molecules that are necessary for T-cell activation. ${ }^{9}$

\section{Dendritic Cells and Herpes Simplex Keratitis-Lessons From the Past}

In the cornea, the presence of atypical dendritic "non-keratinocyte" cells was noted initially by Engelmann. ${ }^{11}$ Constitutive expression of MHC class II antigens was thought to be a characteristic feature of corneal DCs, namely LCs in the peripheral corneal epithelium. ${ }^{12-18}$ Over the last several decades, studies on corneal DCs/LCs, mainly through the use of antiMHC class II antibodies, had led to the dogma that the central normal cornea is essentially devoid of APCs. ${ }^{12,15,19-28}$ However, it has been demonstrated that a variety of corneal stimuli (eg, infection, trauma, contact lens wear), including herpes simplex keratitis, ${ }^{29-35}$ can induce nonspecific LC migration into the cornea from the limbus within days. The migration of LCs has been shown to peak between days 10 and 14 after HSV infection and 
to continue until day 21. ${ }^{35}$ Asbell et al further demonstrated the persistance of LCs in the central cornea of experimental animal after the resolution of HSK. ${ }^{31}$

The number of MHC class $\mathrm{II}^{+}$LCs present in the central areas of the cornea has been shown to correlate with the degree of corneal damage. ${ }^{30}$ The virally induced migration of LCs into the cornea has been shown to precede the development of herptic stromal keratitis. Further, McLeish et al ${ }^{36}$ demonstrated that induction of LC migration into the central cornea before HSV-1 infection results in an accelerated and enhanced delayed type hypersensitivity response to HSV-1 antigens, and in an increase in incidence and severity of HSK. ${ }^{37,38}$ Moreover, depletion of DCs in 1 eye through UV-B irradiation, before bilateral HSV-1 infection, reduces the incidence and severity of stromal disease in infected DC-depleted corneas, ${ }^{32}$ suggesting a role for DCs in the induction of a T-cell response and in the effector phase of the response within the cornea.

These findings have led to the conclusion that HSV-1 infection results in de novo migration of LCs from the limbus, which in turn might play a role in the immunopathology of HSK though the presentation of antigens to $\mathrm{T}$ cells in the infected cornea. It has been proposed that conjunctival LCs are presented with viral antigen, and migrate to the central cornea in response to cytokines expressed by the infected corneal epithelium. ${ }^{35}$ The role of T cells in HSK has been established by Metcalf and Kaufman in 1976, who demonstrated that mice lacking T cells did not develop HSK, concluding that HSK is a T-cell-mediated inflammatory process. ${ }^{39}$ T cells regulate the migration of neutrophils into the cornea through production of interleukin-2 and interferon-g. The destruction of corneal tissue is then mediated by these neutrophils that make up to $90 \%$ of infiltrating cells in $\mathrm{HSK},{ }^{40}$ although the driving force of the chronic inflammation is yet to be determined.

\section{Corneal Dendritic Cells-Recent Updates}

Until very recently, the now disproven absence of professional corneal APCs was thought to translate into suppressed antigen presentation to naive T cells, and further thought to be a critical component of corneal immune privilege. ${ }^{12,24,41}$ This paradigm, however, was recently revised, when studies by Hamrah et al and Liu et al demonstrated that the cornea is indeed endowed with immature resident DCs, including LCs, that undergo maturation after inflammation or transplantation, and are able to migrate to draining lymph nodes. ${ }^{42-46}$

Recent examinations of normal murine corneas have showed that both the peripheral and central areas of the epithelium contain LCs, with the density of these cells decreasing from the limbus $\left(178 \mathrm{LCs} / \mathrm{mm}^{2}\right)$ toward the center $\left(100 \mathrm{LCs} / \mathrm{mm}^{2}\right) .{ }^{43}$ Although a number of mature LCs are MHC class $\mathrm{II}^{+}$in the periphery, as previously shown, a large population of immature/precursor LCs are present both in the periphery and the center of the epithelium, with the center containing exclusively immature LCs. ${ }^{43}$ Further, a recent study of healthy volunteers by in vivo confocal microscopy, has confirmed the presence of LCs in the central human cornea. ${ }^{47}$ Additional confirmation comes from studies of human donor corneal buttons by several laboratories with different sets of standard and newer antibodies. ${ }^{48,49}$

Recent examination of the corneal stroma for APCs has also been performed by several laboratories. ${ }^{42,46,50,51}$ In the initial studies by Hamrah et al, ${ }^{42}$ the presence of significant 
numbers of stromal DCs in the periphery and center of the anterior stroma was noted. The density of these stromal DCs decreased from the limbus $\left(266\right.$ cells $\left./ \mathrm{mm}^{2}\right)$ toward the center of the cornea $\left(135 \mathrm{cells} / \mathrm{mm}^{2}\right)$. Although the stromal periphery contains mature DCs in the normal corneal, the stromal center contains exclusively immature DCs, similar to findings of the highly immature LCs in the epithelium.

Additional evidence for the presence of DCs in the corneal stroma has also been demonstrated by Nakamura et al ${ }^{51}$ through the use of bone marrow (BM) transplantation studies. Intravenous transplantation of BM cells from enhanced green fluorescent protein (GFP) transgenic mice was performed into irradiated wild-type mice and the corneas were examined at 4 to 6 months after transplantation by immunohisto-chemistry. Gradual migration of $\mathrm{GFP}^{+}$DCs takes place into the cornea as soon as 2 weeks after transplantation with distribution throughout the entire cornea at 2 to 6 months. In addition, the presence of DCs in the central corneal stroma of humans has now also been confirmed by Yamagami et $\mathrm{al}^{52}$ and Mayer et al. ${ }^{48}$ Similar to MHC class II-negative immature DCs in the murine stroma, most of the DCs in the human stroma were human leukocyte antigen DR-negative. ${ }^{48}$

The discovery of resident LCs and DCs in the cornea has led to further studies, investigating phenotypic changes of these cells in inflammation. These experiments have demonstrated that a large number of resident immature epithelial $\mathrm{LCs}^{43}$ and stromal DCs ${ }^{46}$ in the center of the cornea are able to undergo maturation as early as 24 hours after induction of inflammation. Most likely, release of pro-inflammatory cytokines, creates a microenvironment that activates immature DCs. In addition to the resident DC population, DCs are also recruited into the cornea from the limbal area during inflammation. Studies by Dana et a ${ }^{53,54}$ have shown that the cornea is able to express proinflammatory cytokines that are upregulated after inflammation and induce migration of DCs, including LCs, into the cornea; conversely, suppression of these cytokines downmodulated DC/LC migration into the cornea. Finally, resident corneal DCs have the ability to travel to draining lymph nodes and sensitize naive $\mathrm{T}$ cells, as recently demonstrated by Liu et al. ${ }^{45}$

\section{A View Into the Future}

The role of DCs in HSK has been elusive. This can be contributed to the fact that the central cornea has historically been thought to be devoid of BM-derived cells, including DCs. The discovery of resident immature DCs and LCs, in the central cornea, has led to a surge in interest in corneal DCs and their role in corneal disease. Our recent studies by in vivo confocal microscopy on patients with HSK, have demonstrated a significant increase in the number of DCs, found in close proximity to the subbasal nerve plexus (Fig. 1). Further, these studies revealed loss of the subbasal nerve plexus, starting immediately after the acute HSV infection, which correlated highly with the loss of corneal sensation in HSK. The evidence that immature resident DCs in the cornea mature as a result of corneal insult and inflammation, leads to the assertion that MHC class $\mathrm{II}^{+}$LCs described in HSK, are not only due to de novo migration of these cells into the corneal center as previously thought, but also, to a large degree, due to maturation of resident DCs. Consequently, the cascade of events leading to herpes simplex keratitis, and the role of DCs in this blinding disease needs to be rethought. 
The purported importance of DCs in the pathophysiology of HSK is underlined by several recent findings in cutaneous HSV that deserve further investigation in the cornea. Neumann et al recently demonstrated that HSV is able to downregulate the T-cell response, by interrupting antigen processing. ${ }^{55}$ In addition, in vitro studies have shown that HSV-1 infection of immature DCs results in downregulation of costimulatory molecules, adhesion molecules, and MHC class I on DCs, ${ }^{56}$ interfering with the recognition of DCs by cytotoxic T cells. Further, HSV-infected DCs secrete lower levels of interleukin-12, mirroring the low maturation stage of these cells and their low stimulatory capacity toward T cells. ${ }^{57}$

The initiation of T-cell-mediated responses to HSV-1 infections has been shown to be critically dependent on the presence of antigen-presenting DCs, which present virus-derived antigens and not the virus itself. ${ }^{58}$ To evade the host immune response, HSV has been shown to induce apoptosis and the elimination of attacking DCs. In combination with a delayed activation of T cells by HSV-infected suppressed DCs, these mechanisms may enable HSV to replicate for a longer time before effective defense strategies of the host are induced. ${ }^{59}$ Moreover, HSV is able to downregulate chemokine (chemotactic cytokine) receptors on mature DCs, inhibiting migration to the draining lymph nodes, and therefore interfering with DC-mediated induction of the antiviral immune response. ${ }^{60}$

In conclusion, HSV has developed several strategies to evade the host immune system. HSV takes advantage of the crucial position of DCs in antigen presentation and stimulation of $\mathrm{T}$ cell. To effectively prevent serious sequelae of HSK, knowledge of the sophisticated interplay of HSV with DCs is crucial. Further studies are required to determine the molecular mechanisms involved in this interplay.

\section{Acknowledgments}

Supported by grants from Charles E.W. Grinnell Fund, the Alice Willard Dorr Foundation, and the New England Corneal Transplant Research Fund.

\section{References}

1. Holland, EJ.; Brilakis, HS.; Schwartz, GS. Herpes simplex keratitis. In: Krachmer, JH.; Mannis, MJ.; Holland, EJ., editors. Cornea. 2nd. St Louis: Mosby; 2005. p. 1043-1074.

2. Pavan-Langston, D. Viral diseases of the cornea and external eye. In: Albert, DM.; Jakobiec, FA., editors. Principles and Practice of Ophthalmology. 2nd. Philadelphia: W.B. Saunders Company; 2000. p. 846-893.

3. Liesegang TJ, Melton LJ III, Daly PJ, et al. Epidemiology of ocular herpes simplex. Incidence in Rochester, Minnesota, 1950 through 1982. Arch Ophthalmol. 1989; 107:1155-1159. [PubMed: 2787981]

4. Liesegang TJ. Classification of herpes simplex virus keratitis and anterior uveitis. Cornea. 1999; 18:127-143. [PubMed: 10090358]

5. Holland EJ, Schwartz GS. Classification of herpes simplex virus keratitis. Cornea. 1999; 18:144154. [PubMed: 10090359]

6. Langerhans P. Über die Nerven der menschlichen Haut. Virchows Arch Path Anat Physiol. 1868; 44:325-337.

7. Steinman RM, Cohn ZA. Identification of a novel cell type in peripheral lymphoid organs of mice. I. Morphology, quantitation, tissue distribution. J Exp Med. 1973; 137:1142-1162. [PubMed: 4573839] 
8. Shortman K, Liu YJ. Mouse and human dendritic cell subtypes. Nat Rev Immunol. 2002; 2:151161. [PubMed: 11913066]

9. Banchereau J, Briere F, Caux C, et al. Immunobiology of dendritic cells. Annu Rev Immunol. 2000; 18:767-811. [PubMed: 10837075]

10. Mellman I, Steinman RM. Dendritic cells: specialized and regulated antigen processing machines. Cell. 2001; 106:255-258. [PubMed: 11509172]

11. Engelmann TW. Über die Hornhaut des Auges. Leipzig. 1867

12. Gillette TE, Chandler JW, Greiner JV. Langerhans cells of the ocular surface. Ophthalmology. 1982; 89:700-711. [PubMed: 7122047]

13. Klareskog L, Forsum U, Malmnäs T, et al. Expression of Ia antigen-like molecules on cells in the corneal epithelium. Invest Ophthalmol Vis Sci. 1979; 18:310-313. [PubMed: 370058]

14. Rodrigues MM, Rowden G, Hackett J, et al. Langerhans cells in the normal conjunctiva and peripheral cornea of selected species. Invest Ophthalmol Vis Sci. 1981; 21:759-765. [PubMed: 6170602]

15. Fujikawa LS, Colvin RB, Bhan AK, et al. Expression of HLA-A/B/C and -DR locus antigens on epithelial, stromal, and endothelial cells of the human cornea. Cornea. 1982; 1:213-222.

16. Whitsett CF, Stulting RD. The distribution of HLA antigens on human corneal tissue. Invest Ophthalmol Vis Sci. 1984; 25:519-524. [PubMed: 6370904]

17. Vantrappen L, Geboes K, Missotte L, et al. Lymphocytes and Langerhans cells in the normal human cornea. Invest Ophthalmol Vis Sci. 1984; 26:220-225. [PubMed: 3882607]

18. Catry L, Van den Oord J, Foets B, et al. Morphologic and immunophenotypic heterogeneity of corneal dendritic cells. Graefe's Arch Clin Exp Ophthalmol. 1991; 229:182-185. [PubMed: 2044982]

19. Rowden G. Expression of Ia antigens on Langerhans cells in mice, guinea pigs, and man. J Invest Dermatol. 1980; 75:22-31. [PubMed: 6446583]

20. Tagawa Y, Takeuchi T, Matsuda H, et al. Distribution and immunologic role of Langerhans cells in ocular surface epithelium. Invest Ophthalmol Vis Sci. 1981; 20(Suppl):2.

21. Jager MJ. Corneal Langerhans cells and ocular immunology. Reg Immunol. 1992; 4:186-195. [PubMed: 1284616]

22. Tuft SJ, Hawkins P, McKenzie JL, et al. The localization of histocompatibility antigens in human cornea. Trans Opthalmol Soc NZ. 1984; 36:36-37.

23. Treseler PA, Foulks GN, Sanfilippo F. The expression of HLA antigens by cells in the human cornea. Am J Ophthalmol. 1984; 98:763-772. [PubMed: 6594932]

24. Mayer DJ, Daar AS, Casey TA, et al. Localization of HLA-A, B, C and HLA-DR antigens in the human cornea: practical significance for grafting technique and HLA typing. Transpl Proc. 1983; 15:126-129.

25. Streilein JW, Toews GB, Bergstresser PR. Corneal allografts fail to express Ia antigens. Nature. 1979; 282:320-321. [PubMed: 574192]

26. Peeler JS, Niederkorn JY. Antigen presentation by Langerhans cells in vivo: donor-derived Ia+ Langerhans cells are required for induction of delayed-type hyper-sensitivity but not for cytotoxic t lymphocyte responses to alloantigens. J Immunol. 1986; 136:4362-4371. [PubMed: 3519767]

27. Pepose JS, Gardner KM, Nestor MS, et al. Detection of HLA class I and II antigens in rejected human corneal allografts. Ophthalmology. 1985; 92:1480-1484. [PubMed: 3909034]

28. Baudouin C, Fredj-Reygrobellet D, Gastaud P, et al. HLA DR and DQ distribution in normal human ocular structures. Curr Eye Res. 1988; 7:903-911. [PubMed: 3053052]

29. Pepose JS. The relationship of corneal Langerhans cells to herpes simplex antigens during dendritic keratitis. Curr Eye Res. 1989; 8:851-858. [PubMed: 2551576]

30. Miller JK, Laycock KA, Nash MM, et al. Corneal Langerhans cell dynamics after herpes simplex virus reactivation. Invest Ophthalmol Vis Sci. 1993; 34:2282-2290. [PubMed: 8389344]

31. Asbell PA, Kamenar T. The response of Langerhans cells in the cornea to herpetic keratitis. Curr Eye Res. 1987; 6:179-182. [PubMed: 3829700] 
32. Hendricks RL, Janowicz M, Tumpey TM. Critical role of corneal Langerhans cells in the CD4- but not CD8-mediated immunopathology in herpes simplex virus-1-infected mouse corneas. $\mathrm{J}$ Immunol. 1992; 148:2522-2529. [PubMed: 1313845]

33. Lewkowicz-Moss SJ, Shimeld C, Lipworth K, et al. Quantitative studies on Langerhans cells in mouse corneal epithelium following infection with herpes simplex virus. Exp Eye Res. 1987; 45:127-140. [PubMed: 3653284]

34. Rosenberg ME, Tervo TMT, Mueller LJ, et al. In vivo confocal microscopy after herpes keratitis. Cornea. 2002; 21:265-269. [PubMed: 11917174]

35. Chen H, Hendricks RL. B7 costimulatory requirements of T cells at an inflammatory site. J Immunol. 1998; 160:5045-5052. [PubMed: 9590254]

36. McLeish W, Rubsamen P, Atherton SS, et al. Immunobiology of Langerhans cells on the ocular surface. II. Role of central corneal Langerhans cells in stromal keratitis following experimental HSV-1 infection in mice. Reg Immunol. 1989; 2:236-243. [PubMed: 2561960]

37. Jager MJ, Atherton S, Bradley D, et al. Herpetic stromal keratitis in mice: less reversibility in the presence of Langerhans cells in the central cornea. Curr Eye Res. 1991; 10:69-73. [PubMed: 1650675]

38. Jager MJ, Bradley D, Atherton S, et al. Presence of Langerhans cells in the central cornea linked to the development of ocular herpes in mice. Exp Eye Res. 1992; 54:835-841. [PubMed: 1325920]

39. Metcalf JF, Kaufman HE. Herpetic stromal keratitis: evidence for cell-mediated immunopathogenesis. Am J Ophthalmol. 1976; 82:827-834. [PubMed: 187060]

40. Thomas J, Gangappa S, Kanangat S, et al. On the essential involvement of neutrophils in the immunopathologic disease: herpes stromal keratitis. J Immunol. 1997; 158:1383. [PubMed: 9013983]

41. Rocha G, Deschênes J, Rowsey JJ. The immunology of corneal graft rejection. Crit Rev Immunol. 1998; 18:305-325. [PubMed: 9704192]

42. Hamrah P, Liu Y, Zhang Q, et al. The corneal stroma is endowed with significant numbers of resident dendritic cells. Invest Ophthalmol Vis Sci. 2003; 44:581-589. [PubMed: 12556386]

43. Hamrah P, Zhang Q, Liu Y, et al. Novel characterization of MHC class II-negative population of resident corneal Langerhans cell-type dendritic cells. Invest Ophthalmol Vis Sci. 2002; 43:639_ 646. [PubMed: 11867578]

44. Hamrah P, Huq SO, Liu Y, et al. Corneal immunity is mediated by heterogeneous population of antigen-presenting cells. J Leukoc Biol. 2003; 74:172-178. [PubMed: 12885933]

45. Liu Y, Hamrah P, Zhang Q, et al. Draining lymph nodes of corneal transplant hosts exhibit evidence for donor major histocompatibility complex (MHC) class II-positive dendritic cells derived from MHC class II-negative grafts. J Exp Med. 2002; 195:259-268. [PubMed: 11805152]

46. Hamrah P, Liu Y, Zhang Q, et al. Alterations in corneal stromal dendritic cell phenotype and distribution in inflammation. Arch Ophthalmol. 2003; 121:1132-1140. [PubMed: 12912691]

47. Zhivov A, Stave J, Vollmar B, et al. In vivo confocal microscopic evaluation of Langerhans cell density and distribution in the normal human corneal epithelium. Graefe's Arch Clin Exp Ophthalmol. 2005; 243:1056-1061. [PubMed: 15856272]

48. Mayer WJ, Irschick UM, Moser P, et al. Characterization of antigen-presenting cells in fresh and cultured human corneas using novel dendritic cell markers. Invest Ophthalmol Vis Sci. 2007; 48:4459-4467. [PubMed: 17898266]

49. Yamagami S, Yokoo S, Usui T, et al. Distinct populations of dendritic cells in the normal human donor corneal epithelium. Invest Ophthalmol Vis Sci. 2005; 46:4489-4494. [PubMed: 16303939]

50. Brissette-Storkus CS, Reynolds SM, Lepisto AJ, et al. Identification of a novel macrophage population in the normal mouse corneal stroma. Invest Ophthalmol Vis Sci. 2002; 43:2264-2271. [PubMed: 12091426]

51. Nakamura T, Ishikawa F, Sonoda KH, et al. Characterization and distribution of bone marrowderived cells in the mouse cornea. Invest Ophthalmol Vis Sci. 2005; 46:497-503. [PubMed: 15671274]

52. Yamagami S, Ebihara N, Usui T, et al. Bone marrow-derived cells in normal human corneal stroma. Arch Ophthalmol. 2006; 124:62-69. [PubMed: 16401786] 
53. Dana MR, Dai R, Zhu SN, et al. Interleukin-1 receptor antagonist suppresses Langerhans cell activity and promotes ocular immune privilege. Invest Ophthalmol Vis Sci. 1998; 39:70-77. [PubMed: 9430547]

54. Dekaris I, Zhu SN, Dana MR. TNF-a regulates corneal Langerhans cell migration. J Immunol. 1999; 162:4235-4239. [PubMed: 10201952]

55. Neumann J, Eis-Hubinger AM, Koch N. Herpes simplex virus type 1 targets the MHC class II processing pathway for immune evasion. J Immunol. 2003; 171:3075-3083. [PubMed: 12960333]

56. Mikloska Z, Bosnjak L, Cunningham AL. Immature monocyte-derived dendritic cells are productively infected with herpes simplex virus type 1. J Virol. 2001; 75:5958-5964. [PubMed: 11390597]

57. Pollara G, Speidel K, Samady L, et al. Herpes simplex virus infection of dendritic cells: balance among activation, inhibition, and immunity. J Infect Dis. 2003; 187:165-178. [PubMed: 12552441]

58. Mueller SN, Jones CM, Smith CM, et al. Rapid cytotoxic T lymphocyte activation occurs in the draining lymph nodes after cutaneous herpes simplex virus infection as a result of early antigen presentation and not the presence of virus. J Exp Med. 2002; 195:651-656. [PubMed: 11877488]

59. Jones CA, Fernandez M, Herc K, et al. Herpes simplex virus type 2 induces rapid cell death and functional impairment of murine dendritic cells in vitro. J Virol. 2003; 77:11139-11149. [PubMed: 14512561]

60. Prechtel AT, Turza NM, Kobelt DJ, et al. Infection of mature dendritic cells with herpes simplex virus type 1 dramatically reduces lymphoid chemokine-mediated migration. J Gen Virol. 2005; 86:1645-1657. [PubMed: 15914842] 


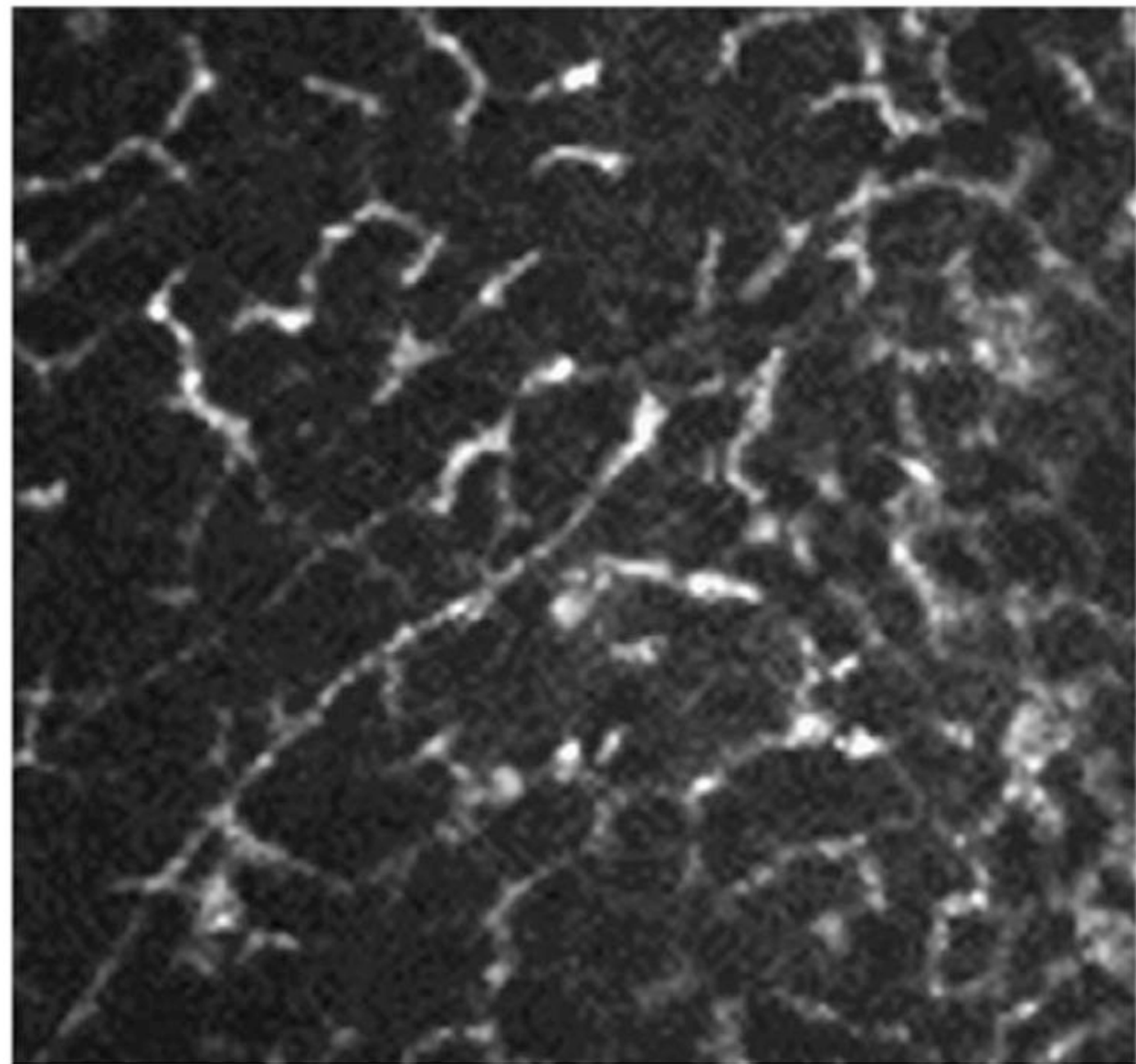

Figure 1. Large number of dendritic cells found in close proximity to the subbasal nerve plexus in patients with severe herpes simplex keratitis 